\title{
"Geology in Everyday Life": Designing Museum Educational Programmes (EP) with Students of Geology in the Science and Technology Museum (STM) of the University of Patras, Greece ${ }^{\dagger}$
}

\author{
Penelope Theologi-Gouti ${ }^{1, *}$, Ioannis Iliopoulos ${ }^{1,2}$ and Maria Kokkaliari ${ }^{2}$ \\ 1 Science and Technology Museum, University of Patras, 26504 Patras, Greece; morel@upatras.gr \\ 2 Department of Geology, University of Patras, 26504 Patras, Greece; kokkaliarimaria@gmail.com \\ * Correspondence: penythg@upatras.gr; Tel.: +30-2610969973 \\ + Presented at International Conference on Raw Materials and Circular Economy, Athens, Greece, \\ 5-9 September 2021.
}

check for

updates

Citation: Theologi-Gouti, P.;

Iliopoulos, I.; Kokkaliari, M.

"Geology in Everyday Life":

Designing Museum Educational

Programmes (EP) with Students of

Geology in the Science and

Technology Museum (STM) of the

University of Patras, Greece. Mater.

Proc. 2021, 5, 101. https://doi.org/

10.3390/materproc2021005101

Academic Editor: Evangelos

Tzamos

Published: 14 January 2022

Publisher's Note: MDPI stays neutral with regard to jurisdictional claims in published maps and institutional affiliations.

Copyright: (c) 2022 by the authors. Licensee MDPI, Basel, Switzerland. This article is an open access article distributed under the terms and conditions of the Creative Commons Attribution (CC BY) license (https:// creativecommons.org/licenses/by/ $4.0 /)$.

\begin{abstract}
This paper describes a study case of the Science and Technology Museum "Pedagogical Competence Programme" for students of the Department of Geology. It highlights an experimental approach of the museum for designing museum educational programmes with students. The museum succeeded from one side to develop a new program to offer to schools using participatory design and from the other to offer university students pedagogical experience through innovative, non-formal educational programmes, new ways to approach school students at all levels, cultivate their special skills, and enhance their knowledge, in order to familiarise them with the popularisation of science.
\end{abstract}

Keywords: museum education; participatory design; popularisation of science; communication of science; students; geology; scientific literacy

\section{Introduction}

At the beginning of the academic year 2019-2020, the Science and Technology Museum (STM) of the University of Patras, Greece developed and proposed to the School of Natural Sciences' Departments a "Pedagogical Competence Programme" (PCP) for fourth year students. The main goals of this innovative programme are to help students gain pedagogical experience through innovative non-formal educational activities, discover ways to approach school students at all levels, cultivate their special skills, imagination and creativity and benefit from their knowledge on the science they study, in order to familiarise them with the popularisation of science.

The Department of Geology was the first to respond to this challenge. The PCP for students of geology offers students a number of informative and experiencial activities, including participation in the planning of a museum educational programme (ED) on geology.

The "Pedagogical Competence Programme" is experimental and interactive and enhances the Museum's co-creation activities as well as its relationship with students. It created a strong link with students of geology that is strengthened over time. On one hand, it succeeded in welcoming the students' skills to the museum, to deliver new museum educational programmes to offer to schools using participatory design and to enrich services offered by the Science and Technology Museum in different fields. On the other, it succeeded in offering university students pedagogical experience in approaching school students, the ability to work together and design innovative educational activities, the challenge to discover and cultivate their special personal skills and the know-how to popularise science through innovative methods and activities. It finally succeeded in engaging university students in transforming their knowledge on science into enjoyment while contributing to the scientific literacy of society [1], (pp. 4-7). 
We consider that the outcomes of the "Pedagogical Competence Programme" served its aims and it constitutes "good practice" for working with students in a university museum to promote science for all and the scientific literacy of students of all levels and society.

\section{The Science and Technology Museum as an Educational Tool}

University museums (UM) offer enormous potential to universities as they embrace the universities' research culture of innovation and experimentation. Many university museums worldwide are taking risks in developing new ways of working with audiences to explore complex and challenging issues. As long as they are accessible, they are inspiring university community resources that offer ways to engage with school groups among other social and cultural groups who might not otherwise engage with the university [1], (p. 9).

For that reason, the Science and Technology Museum was founded in 2001 as a Laboratory of the School of Natural Sciences by the University of Patras, Greece with the core goal to connect the university with the city and society of Patras. The museum also aims to connect the three levels of education and to contribute to the scientific and technological literacy of students, teachers and society. It opened to the public in 2009, after the completion of one of the three wings of its main building [2], (p. 57).

A visit to the Science and Technology Museum or participation in one of its educational programmes is probably the first contact with a higher education institution for many children and young people. The museum can provide friendly and engaging experiences, and hence play an important role in stimulating an interest in further study and overcoming barriers to higher education. The museum's work through widening participation of the target schools helps to raise and broaden the aspirations of children, their families and teachers and to enhance awareness in issues where scientific knowledge, art and the environment interlock [1], (p. 8).

Thus, the Science and Technology Museum plays the role of the mediator between the University of Patras and society in order to link them. The museum succeeded in playing the dual role every university museum should play: serving society while serving the University [2], (pp. 57-58).

To fulfill its dual role, on one hand the Science and Technology Museum has developed different educational tools to communicate with society. The means of communication include, but are not limited to, its permanent exhibition, temporary exhibitions on science, technology, arts and the environment, as well as their relationship, educational programmes for schools on the permanent and temporary exhibitions, different events, workshops and seminars for different parts of society, thematic school networks, nationwide contests, a newsletter and the museum's site. They permit the museum to offer high-quality, nonformal educational services to different levels of society [3], (p. 52). The proof that the wider educational community appreciates those services is highlighted by the increasing number of visitors: 10.000 visitors in 2009 and >44.000 visitors in 2019 before the pandemic, of which $\sim 80 \%$ were school students and teachers.

The museum organises and operates educational programmes for school groups from kindergarten to high school that include treasure hunt games, performing arts activities, puzzles, interactive activities on computers, interactive experiments and educational games. They help school children approach science and technology using experimentation and participatory techniques, not just to give them a voice, but to develop experiences that are more valuable and compelling to them expressing themselves [4], (pp. 3-8).

The Science and Technology Museum has also succeeded in approaching and activating the university society and students, not only those studying in Patras University, but also in other Greek universities or abroad. It offers them a pleasant place for experimentation, experience and innovation, through volunteering, internship and the pedagogical competence program, by engaging them in Museum life.

Thereby the Science and Technology Museum has succeeded in connecting the three levels of education. It finally serves as a platform that connects different users as university 
and school students, school teachers, university professors and staff, people with special needs and other different publics [4], (pp. 3-13). This connection has started to produce a number of benefits for the University of Patras and might serve as a broadcast for attracting high-level school students to choose Patras University for studying.

\section{Designing Museum Educational Programmes with Students of Geology}

At the beginning of the academic year 2019-2020 the Science and Technology Museum developed and proposed to the Departments of the School of Natural Sciences' of which it is a Laboratory, the "Pedagogical Competence Programme" (PCP) for fourth year students. The programme aims to offer students of the School of Natural Sciences pedagogical experience by encouraging them to discover, cultivate and use their special skills, imagination and creativity, to deepen and use their knowledge on the science they study, to discover and develop innovative non-formal educational activities, to cultivate and extend their communication ability and discover ways to approach school students at all levels, in order to familiarise them with the popularisation of science. The Department of Geology was the first to respond to this challenge. Nine to twelve students have participated in this programme every semester since October 2019.

The "Pedagogical Competence Programme" for students of the Geology Department of the University of Patras is experimental, interactive and flexible. The purpose of students' participation is to obtain a "certificate of participation", as a discipline-specific skill [5], (pp. 5-6). It is one of the five conditions required according to the Reformed Curriculum of the Department of Geology. Students participate every winter or spring semester of each year. The duration of the programme is fourteen weeks and students must spend one day each week in the museum. Finally, in addition to the certificate of educational competence, students receive a diploma of voluntary participation in STM in December of the next academic year in the context of the International Volunteering Day, as recognition for the time and energy spent by engaging with the Science and Technology Museum [6], (pp. 15-28).

Students' training starts with a workshop in which they learn about the museum's goals, objectives and activities. Experiential training follows and includes presentation of museum educational programmes and analysis of their objectives. Students are trained as museum educators/animators. They follow all school educational programmes during their museum day. When they feel confident, they implement educational programmes as animators, together with more experienced students while the person in charge of the PCP monitors discreetly. At the end of every day, all together, students, museum staff and the person in charge, discuss and evaluate their experience.

One of the students' important activities during the PCP is to participate in the planning of a museum educational programme on geology by designing a presentation/story, or experiment or activity. All students participating in the semester's PCP meet with the person in charge of brainstorming for that purpose. Thus, the first group of students who participated during the winter semester from October 2019-February 2020, after three meetings, co-decided the topic of the educational programme to develop. It is "Geology in everyday life" and it is designed for secondary education.

After discussing the goals of the educational programme, the topics to be addressed and the general guidelines, the students were divided into working groups that had to tackle one of the following topics: introduction, geology in human life, house construction, technology and the environment. The groups have worked separately in close collaboration with the responsible of the Pedagogical Competence Programme and developed fairy tales/stories and presentations. An important challenge for the students was to manage flexible communicational methods aimed at younger ages, offering their knowledge via pleasant and entertaining presentation material. Their creative work was evaluated and corrected by experts and the fairy tales were illustrated during summer 2020 and given afterwards to groups of students of the winter semester 2020-2021 to enrich them. 
The COVID-19 pandemic has drastically changed the routine of the Pedagogical Competence Programme. The museum was closed, and a number of educational programmes for schools were transformed to be offered virturally through an online platform. So, students were trained and met through the internet and online educational programmes were offered to schools by Webex or Zoom. Those groups of students developed interactive educational activities for each part of the educational programme, such as board games, role-playing games, recognition and identification/matching games (Figure 1).
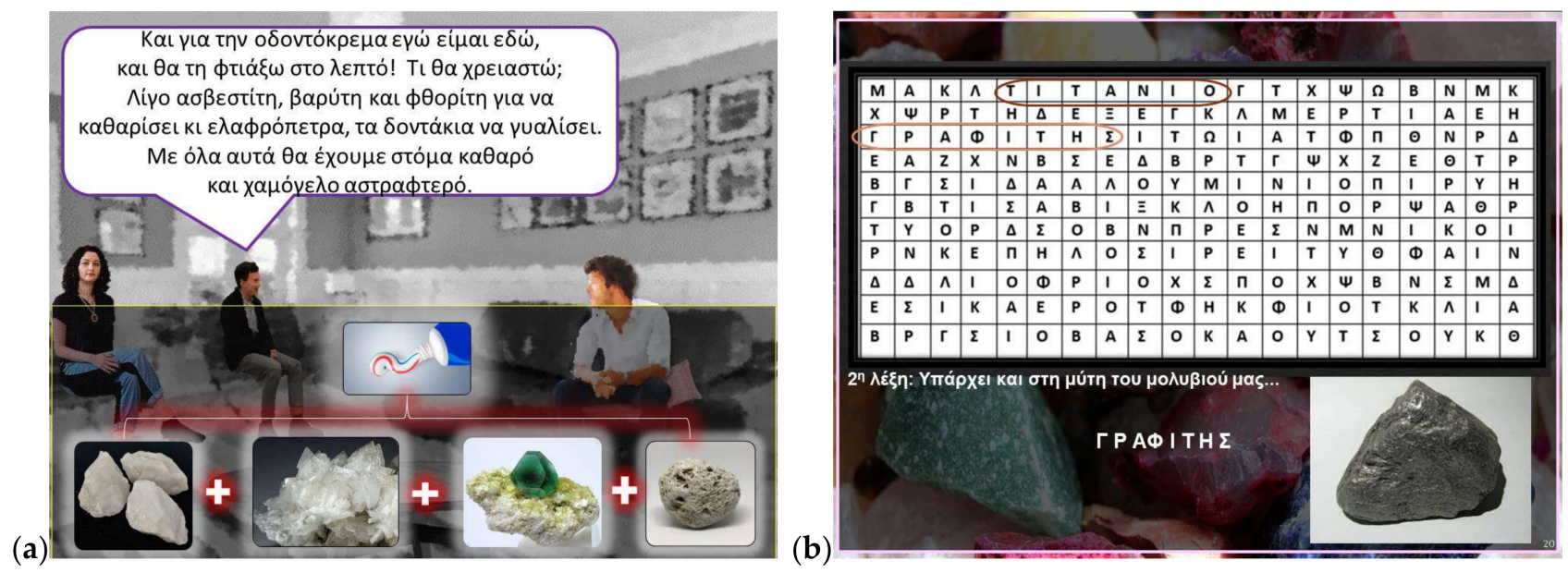

Figure 1. Snapshots from: (a) the first part story/roleplay game "Geology in our lives"; (b) the recognition/identification game "Geology in technology".

After a second evaluation, the museum educational programme is ready and offers the first insight through the science of geology, noting that geology is all around us even if sometimes it is not perceived. The evolution of the earth and, as a result of human evolution, the utilisation of earth raw materials, as well as the protection of the environment, are important issues in our lives and their study is considered necessary for our near future. When the PCP started the museum did not hold any collection of geological material. In the meantime, the museum acquired a small collection of earth raw materials by a donation and a loan for the purpose of the EP. It strives to multiply this collection with the purpose of developing a permanent exhibition on geology.

Additional educational material for schoolteachers willing to participate with their students to the educational programme, "Geology in everyday life", has been developed. It includes the EP's poster and a leaflet advising teachers how to prepare students for the participation in the educational programme and how to reclaim this experience when back to school. The educational programme "Geology in everyday life" will be added to the list of educational programmes the museum offers for secondary education groups of school students. The "Pedagogical Competence Programme" enhanced the museum's co-creation activities as well as its relationship with students. It created a strong link with students of geology that multiplied over the time. During their museum experience, students acted as content creators, story-tellers, distributors, consumers, critics and collaborators. For example, the museum staff and university students worked or played with school children, or developed activities or experiments for children; children and teachers participated in activities specially organised by the museum staff with university students for various levels of knowledge (Figure 2); teachers and children collaborated in setting up activities in collaboration with the museum staff and university students [3], (p. 9). 


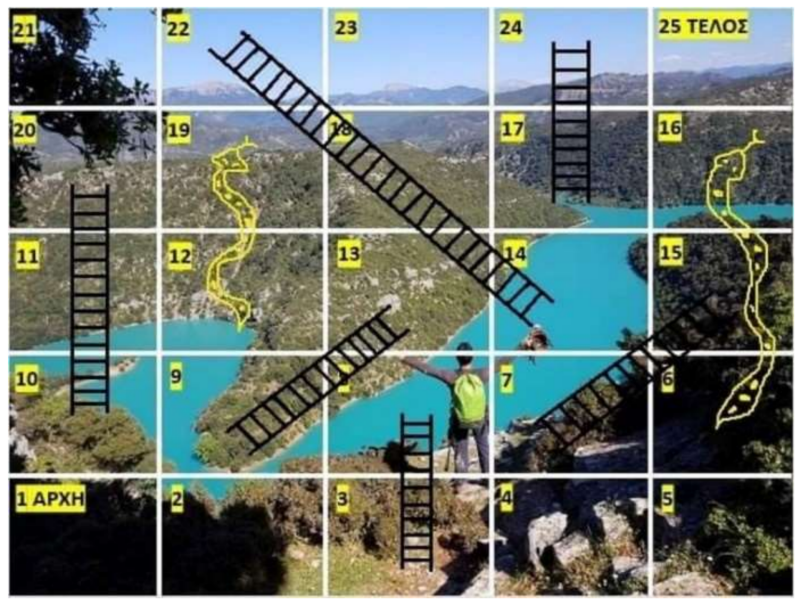

Figure 2. Snapshot from the board game "Environment".

By giving the opportunity to experience participatory methods, the Science and Technology Museum offers students the opportunity to open up new ways of communicating science, deepen their knowledge, express themselves and engage with institutional practice by developing successful ways to attract and educate the public. These activities are making the science of geology easy to understand. The enthusiasm of students to participate in the program and their involvement conveying their knowledge though an educational perspective, have positive effect, encouraging more students to participate every year.

Through involvement in the museum educational programmes, students are able to develop a wide range of transferable real-world employability skills: self-discipline, confidence, project management, team working and communications. Furthermore, these activities provide opportunities for students to develop their subject specialist skills and gain experience directly relevant to employment in the wider academic, educational, cultural and creative sectors. Such projects offer students the chance to take the lead in engaging the public with their subject matter and research and to consider how their studies can impact and benefit the wider community, while at the same time, museum visitors benefit from students' energy and fresh perspective [1], (p. 6).

Together with students participating in the PCP in the spring semester 2020-2021 the museum staff has started to develop a new educational programme on geology for the 5th and 6th grades of primary education using a similar procedure. This programme will be entitled "Young detectives discover the earth raw materials in our lives".

\section{Result: The Museum Educational Programme "Geology in Everyday Life"}

The Educational Programme "Geology in everyday life" developed in collaboration with geology students participating in the "Pedagogical Competence Programme" of winter semesters 2019-2020 and 2020-2021, will be offered to schools, starting from the academic/school year 2021-2022, as long as universities and, consequently, university museums are open (Figure 3). It is not designed to be implemented through a platform, but it can be transformed if the pandemic continues. To implement the developed programme to school groups, at least two trained students/animators are needed.

"Geology in everyday life" is developed for school groups of secondary education. It can be implemented both in high school and in junior high school groups, as a number of additional activities have been developed for high school groups. It is interactive, experiential and playful. STM uses games in order to enhance knowledge, as school students are used to playing and games are satisfying for teens [7], (p. 113).

The developed EP aims to make school students enjoy their museum visit while participating. The educational material developed for the programme within the PCP uses clear language considering the school students' cognitive level that makes them understand the role that earth raw materials play in our lives, has a clear structure both for animators 
and school groups and triggers students' curiosity, critical thinking and creativity [8], (p. 95).
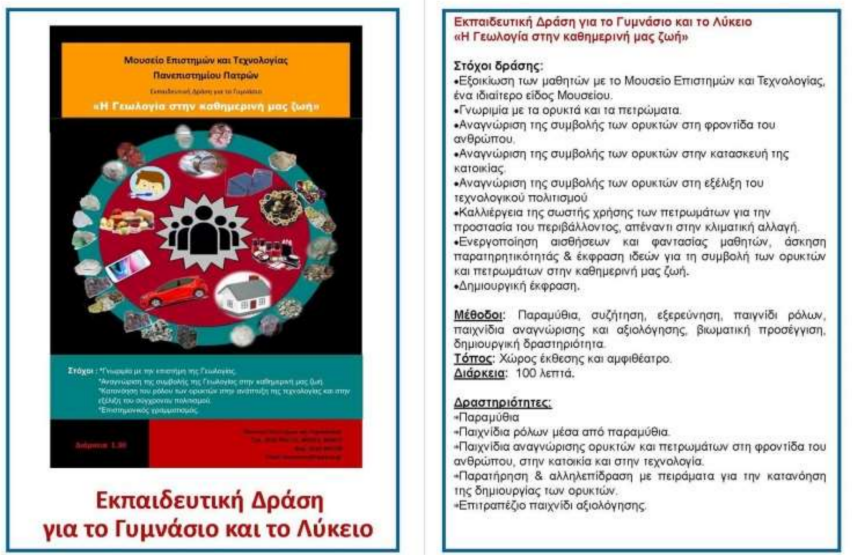

Figure 3. The informational leaflet circulated to school teachers for the Educational Programme "Geology in everyday life".

The duration of the EP is approximately one and a half hours and school groups participating should not exceed 25 students. It is addressed not only to schools of the Achaia region, where the university is located, but to any school group willing to visit the Science and Technology Museum of the University of Patras. School groups willing to participate in the programme should make an appointment in advance.

According to "Geology in everyday life" EP planning, school students of each group sometimes participate or watch, observe, listen and play all together and other times they are divided into smaller groups. The educational programme is divided into three parts. Primarily, animators will guide every school group to STM's amphitheatre. The programme starts and ends there. At the beginning, school students participate in a short introduction/presentation on the big screen and then a story/fairy tale on "geology in our lives". We introduce the science of geology with a travel through time, when our ancestors used minerals as tools, facilitating their everyday life. Then, we present the ways that our mineral resources are used in our present and in the near future and the necessities that arise from the way we live. The story comes to life with school students reading the dialogues as a role-playing game in order to activate teens' sense of participation as much as possible [7], (p. 113). Then, school students are divided into two groups and play a recognition and identification/matching game in order to match objects used in human life with earth raw materials. The purpose is to help students imprint the general idea of the science of geology through an entertaining process.

During the second part, school students stay divided in two groups and every group is guided by an animator in a different part of the museum exhibition. One group will be working with earth raw materials in house construction, learning also briefly about the rock cycle related to specific tectonic environments, as well as that minerals and rocks are characterised by specific properties which make them so valuable to us. The other will learn how the earth's raw materials are used in technology, giving everyday examples, and also focusing on the processes required for the study of the geological formations in the earth's surface in order to recognise an ore deposit and the important contribution of landscape restoration. Each group will participate in a presentation and will play a recognition and identification/matching game on the theme. At the end of this session, each group will write a few words on the session it participated in, in order to exchange experiences with the other group when coming back to the amphitheatre.

Both groups are coming to the amphitheatre for the third and final session. After exchanging their experiences on "geology in house construction" and "geology in technology" 
they participate in a session on the environment. They watch and bring a story/fairy tale about the "environment" to life, by reading the dialogues, as a role-playing game. Finally, they are divided into groups of four to five students. Every group plays the same board game to evaluate their experience of the programme. The group that finishes the game first will be the winner.

\section{Conclusions}

We consider that the outcomes of the "Pedagogical Competence Programme" served its aims till today and has the potential to multiply its benefits. By implementing the PCP, the Science and Technology Museum of the University of Patras succeeded from one side to develop one new educational programme to offer to schools and another one that will be ready very soon. They are both offering benefits for understanding science, especially geology, using participatory design.

We believe that through this program, when implemented, students will discover the beauty of the science of geology and its importance for our lives. These activities promoted the science of geology to younger students, by familiarising them with the important contribution of geology through our evolution and, more importantly, in our everyday life, using interesting, pleasant and interactive means. The interest received from the students getting to know different aspects from geology has proven to be extremely appealing.

The museum also succeeded in introducing university students to a new way of thinking and dealing with science. By participating in the PCP, university students gain pedagogical experience through innovative non-formal educational programs and discover new ways to approach school students at all levels. They discover, cultivate and use their special skills, and enhance their knowledge, in order to familiarise themselves with the popularisation of science.

Thus, the Science and Technology Museum is building a strong relatioship with the students of the Department of Geology of the University of Patras that supports its effort to serve society while serving the university community. By implementing the PCP, the museum is gaining additional value within the university, the wider educational community and society [1], (p. 12).

The museum is willing to continue the "Pedagogical Competence Program" with the Department of Geology and will experiment with students in the design of other educational media for communicating science in the form of thematic exhibitions, thematic networks, educational programmes for families, etc. It will also try to convince other Departments of the School of Natural Sciences to participate in the "Pedagogical Competence Program".

The Pedagogical Competence Programme constitutes a "good practice" for working with students in a university museum to promote science for all and the scientific literacy of students of all levels and society. It also constitutes a "good practice" for creating efficient scientific popularisation material for school students of different levels, highlighting the role of the museum as an education hub interconnecting the three levels of education.

Author Contributions: Conceptualization, P.T.-G. and I.I.; methodology, P.T.-G.; software, P.T.-G.; validation, P.T.-G., I.I. and M.K.; formal analysis, M.K.; investigation P.T.-G.; resources, M.K.; data curation, P.T.-G.; writing—original draft preparation, P.T.-G.; writing—review and editing, P.T.-G., I.I. and M.K.; visualization, P.T.-G. and M.K.; supervision, I.I.; project administration, P.T.-G. All authors have read and agreed to the published version of the manuscript.

Funding: This research received no external funding.

Institutional Review Board Statement: Not applicable.

Informed Consent Statement: Not applicable for studies not involving humans.

Data Availability Statement: The study did not report any data.

Conflicts of Interest: The authors declare no conflict of interest. 


\section{References}

1. UMG-University Museums for the 21st Century. Available online: http://umac.icom.museum/wp-content/uploads/2017/05/ UMG-UMIS_ADVOCACY-single.pdf (accessed on 20 June 2021).

2. Theologi-Gouti, P.; Vitoratos, E. University Museums as Mediators between University and Society: The exemple of Patras university Science and Technology Museum. In Turning Inside Out European University Heritage: Collections, Audiences, Stakeholders; National and Kapodistrian University of Athens: Athens, Greece, 2018; pp. 57-66.

3. Theologi-Gouti, P.; Vitoratos, E. The role of the Science and Technology Museum in the development of Patras University Cultural Landscape. UMACJ 2017, 9, 51-59.

4. Simon, N. The Participatory Museum; MUSEUM 20: Santa Cruz, CA, USA, 2010.

5. A Guide to Student Volunteering in Museums-University of Reading UK. Available online: https://www.reading.ac.uk $\backslash$ T1 $\backslash$ guilsinglrightvolunteersformuesums (accessed on 17 June 2021).

6. Cutler, N. Working with volunteers. In The Museum Educators Manual, 1st ed.; Johnson, A., Huber, K.A., Cutler, N., Bingmann, M., Grove, T., Eds.; Altamira Press: Plymouth, UK, 2009; pp. 15-29.

7. Theologi-Gouti, P.; Vitoratos, E. The Conversation of Sciece, Technology and Performing Arts in the Science and Technology Museum UP. In Proceedings of the 1st Conference Performing arts in Education: Collectivity and Consolation Patras, Patras, Greece, 17 May 2016; pp. 110-120.

8. Gesché-Koning, N. Communicating scientific information to the general public. UMACJ 2016, 7, 92-99. 